\title{
Pengaruh Model Pembelajaran Cooperative Tipe Two Stay Two Stray (TSTS) dengan Media Whatsapp terhadap Prestasi Belajar Matematika Siswa Kelas VII SMP Negeri 1 Maros
}

\author{
Sitti Asriyanti ${ }^{1}$, Ernawati ${ }^{2}$, Rizqi Ashari Rahim ${ }^{3}$ \\ 1) 2) 3) Universitas Muslim Maros \\ 1) asriyantisitti@gmail.com \\ 2) ernafajar1305@gmail.com \\ 3) rizqiazharirahim@gmail.com
}

\begin{abstract}
ABSTRAK
Jenis penelitian ini adalah penelitian kuantitatif dengan one group pretest-posttest desain. Populasi dalam penelitian ini adalah siswa kelas VII SMP Negeri 1 Maros dengan sampel yang dipilih menggunakan metode Simple random sampling, sebanyak 12 siswa dalam satu kelas eksperimen yaitu kelas VII F. Pengumpulan data menggunakan tes prestasi belajar matematika dan lembar observasi yang telah divalidasi oleh ahli. Data penelitian ini dianalisis secara deskriptif dan inferensial dengan uji normalitas sebagai uji prasyarat analisis dan uji paired sample t-test sebagai uji hipotesis. Hasil analisis data menunjukkan bahwa rata-rata hasil pretest 46,83, sedangkan rata-rata posttest 84.25 . Berdasarkan uji-t diperoleh $0,000<\alpha=0,025$ yang berarti terdapat pengaruh yang signifikan pada siswa yang diajar menggunakan model pembelajaran cooperative tipe Two Stay Two Stray (TSTS) dengan media whatsapp terhadap prestasi belajar matematika siswa kelas VII SMP Negeri 1 Maros. Hasil penelitian ini menunjukkan bahwa terdapat pengaruh signifikan hal ini ditunjukkan dengan menggunakan model pembelajaran two stay two stray dengan media whatsapp pada materi bangun datar segiempat terhadap prestasi belajar matematika kelas VII SMP Negeri 1 Maros.
\end{abstract}

Kata Kunci: Model Pembelajaran Cooperatif, Two Stay Two Stray (TSTS), Media Whatsapp, Prestasi Belajar Siswa, Matematika

\begin{abstract}
This type of research is a quantitative study with one group pretest-posttest design. The population in this study were students of class VII SMP Negeri 1 Maros with a sample selected using the simple random sampling method, as many as 12 students in one experimental class, namely class VII F. Data collection used mathematics learning achievement tests and observation sheets that have been validated by experts. The research data were analyzed descriptively and inferential with the normality test as the prerequisite test for analysis and paired sample t-test as the hypothesis test. The results of data analysis showed that the average pretest result was 46.83 , while the posttest average was 84.25 . Based on the $t$-test, it was obtained $0.000<\alpha=$ 0.025 , which means that there is a significant effect on students who are taught using the Two Stay Two Stray (TSTS) cooperative learning model with WhatsApp media on the mathematics learning achievement of class VII students of SMP Negeri 1 Maros. The results of this study indicate that there is a significant influence this is indicated by using the two stay two stray learning model with WhatsApp media on the rectangular flat shape material on the mathematics learning achievement of class VII SMP Negeri 1 Maros.
\end{abstract}

Keywords: Cooperative Learning Model Type Two Stay Two Stray (TSTS), Whatsapp Media, Student Achievement, Mathematics. 


\section{A. PENDAHULUAN}

Pendidikan merupakan elemen yang sangat penting untuk menciptakan sumber daya yang berkualitas, cerdas, damai terbuka, demokratis, dan mampu bersaing serta dapat meningkatkan kesejahteraan semua warga negara Indonesia (Supriatin\& Wakijo, 2018). Undang-undang No.20 Tahun 2003 tentang Sistem Pendidikan Nasional menyatakan bahwa pendidikan adalah usaha sadar dan terencana untuk mewujudkan suasana belajar dan proses pembelajaran agar siswa secara aktif mengembangkan potensi dirinya untuk memiliki kekuatan spiritual keagamaan, pengendalian diri, kepribadian, kecerdasan, akhlak mulia, serta keterampilan yang diperlukan dirinya, masyarakat, bangsa dan negara (Gani, 2015).

Menurut Gani(2015) penelitian difokuskan pada upaya untuk mengatasi faktor internal seperti rendahnya minat dalam belajar yang diduga menjadi penyebab rendahnya tingkat keaktifan siswa dalam belajar sehingga hasil belajar siswa pada tingkat SMP Negeri di Kecamatan Salomekko Kabupaten Bone masih sangat rendah, karena kurang inovatif dan kreativitas guru dalam menggunakan model pembelajaran sehingga kegiatan pembelajaran berlangsung monoton dan membosankan. Salah satu model pembelajaran yang diduga mampu mewujudkan situasi pembelajaran yang kondusif, aktif, kreatif, efektif, dan menyenangkan adalah dengan model pembelajaran two stay two stray dimana siswa yang melakukan proses dalam setiap kelompok belajar(Gani, 2015).

Berdasarkan hasil observasi dalam bentuk wawancara salah satu guru matematika pada tanggal 25 November 2019 di SMP Negeri 1 Maros Kelas VII peneliti peroleh, bahwa : 1) Model pembelajaran yang digunakan oleh guru dalam kegiatan belajar mengajar belum bervariasi, masih didominasi oleh guru sehingga siswa cenderung bosan, 2) minat siswa dalam proses belajar masih rendah ini bisa dilihat pada saat proses pembelajaran berlangsung masih banyak yang tidak memperhatikan, 3) siswa kurang aktif dan terlibat dalam proses belajar mengajar yang ditandai siswa jarang bertanya kepada guru, 4) hasil belajar yang tidak optimal, ditandai nilai ulangan harian untuk mata pelajaran matematika rendah. Dan berdasarkan hasil rapor dari salah satu siswa kelas VII F menunjukkan bahwa prestasi belajar matematika siswa masih sangat rendah karena memperoleh nilai yang sangat rendah yaitu 58 atau predikat $\mathrm{C}$ dari nilai standar KKM 75.

Sehubung dengan adanya pandemic covid 19 penyakit mematikan ini yang dapat menular dengan cepat baik bagi dewasa maupun anakanak bahkan umur yang sudah lanjut usia dan pandemic covid 19 ini dapat menular dengan cepat jika sering terjadi perkumpulan kelompok salah satunya yaitu sekolah, karena besar kemungkinan terjadi perkumpulan kelompok tersebut dan adapun langkah-langkah yang saya terapkan dalam penelitian saya untuk mencegah adanya penularan covid 19 yaitu 
saya melakukan penelitian melalui metode pembelajaran Two Stay Two Stray dengan media WhatsApp demi mencegah penyebaran covid 19.

\section{B. METODE}

Jenis penelitian ini adalah jenis penelitian pra-eksperimen dengan menggunakan perlakuan pada objek penelitian dengan melibatkan satu kelompok kelas saja sebagai kelas eksperimen tanpa kelas pembanding. Perlakuan yang dimaksud adalah penerapan model pembelajaran cooperative tipe Two Stay Two Stray dalam pembelajaran. Jenis penelitian ini digunakan untuk meneliti (mengetahui) ada atau tidaknya pengaruh penerapan model pembelajaran cooperative tipe Two Stay Two Stray dengan media whatsapp terhadap prestasi belajar siswa pada mata pelajaran matematika di kelas VII SMP Negeri 1 Maros.

Pada penelitian ini yang menjadi sampel adalah peserta didik kelas VII F SMP Negeri 1 Maros yang terdiri dari 32 siswa.

Adapun instrumen penelitian data yang digunakan dalam penelitian ini adalah:

a. Lembar Observasi

lembar observasi adalah lembar yang digunakan untuk menuliskan hasil observasi yang dilakukan saat proses pembelajaran berlangsung dengan tujuan.

b. Tes

Tes adalah suatu alat yang digunakan untuk mengukur keterampilan, pengetahuan serta kemampuan yang dimiliki kelompok atau individu. Tes prestasi belajar ini diperoleh dari model pembelajaran two stay two stray untuk melihat apakah ada pengaruh atau tidak.

c. Dokumentasi

Dokumentasi merupakan pengumpulan data dengan mengambil gambar dari proses belajar mengajar.

Teknik pengumpulan data yang dilakukan dalam penelitian eksperimen ini adalah:

a. Statistik Deskriptif

Statistik deskriptif digunakan untuk mendekripsikan prestasi belajar siswa berupa rata- rata, median, standar deviasi. Selain itu, dalam penelitian ini akan dideskripsikan perbedaan yang terjadi sesudah siswa diberi perlakuan. Perbedaan tersebut akan ditinjau berdasarkan perhitungan nilai gain ternormalisasi. Nilai gain ternormalisasi dalam penelitian ini diperoleh dengan membagi skor gain (selisih posttest dan pretest) dengan selisih antara skor posttest dengan skor pretest.

b. Statistik Inferensial

Statistika inferensial digunakan untuk menguji hipotesis penelitian. Dalam penelitian ini digunakan analisis statistika Paired Sample T-test untuk menguji hipotesis penelitian. Namun sebelum dilakukan uji hipotesis, terlebih dahulu dilakukan uji normalitas. 


\section{HASIL PENELITIAN}

\section{Deskripsi Penelitian}

Penelitian ini dilaksanakan di SMP Negeri 1 Maros dengan mengambil kelas VII F sebagai sampel. Hasil penelitian ini menggambarkan prestasi belajar peserta didik sebelum dan sesudah diberikan perlakuan berupa penerapan model cooperative tipe Two Stay Two Stray (TSTS) dengan media whatsapp pada kelas eksperimen.

Penelitian ini dilaksanakan pada tanggal 0412 Mei 2020 selama empat pertemuan. Pertemuan pertama berupa pemberian materi dan pretest, pada pertemuan kedua dan ketiga berupa pelaksanaan model pembelajaran cooperative tipe Two Stay Two Stray, dan pada pertemuan keempat pelaksanaan posttest. Adapun jenis tes yang diberikan berupa soal essay sebanyak 5 butir soal yang telah divalidasi sebelumnya. Prestasi Belajar Sebelum diterapkan Model Pembelajaran cooperative tipe Two Stay Two Stray (TSTS) dengan Media

\section{Whatsapp.}

a. Deskripsi Data Prestasi Belajar Sebelum Penerapan Model Pembelajaran Two Stay Two Stray (TSTS) dengan Media Whatsapp.

Tabel 1. Rekapitulasi Prestasi Belajar Pretest

\begin{tabular}{|c|c|}
\hline & Pretest \\
\hline $\mathrm{N}$ & 12 \\
\hline Rata-rata & 46,83 \\
\hline Median & 46,00 \\
\hline Nilai Minimum & 35 \\
\hline Nilai Maksimum & 56 \\
\hline Standar Deviasi & 5,573 \\
\hline
\end{tabular}

Berdasarkan pada tabel dapat dlihat hasil dari tes sebelum penerapan model pembelajaran cooperative tipe two stay two stray dengan media whatsapp, dengan jumlah siswa yang mengikuti pretest yaitu 12 siswa dari 32 siswa. Adapun nilai rata-rata dan median yang diperoleh siswa adalah 46,83 dan 46,00, sedangkan nilai minimum dan maksimum dari tes sebelum diterapkan model pembelajaran cooperative tipe two stay two stray dengan media whatsapp adalah 35 dan 56. Dapat dilihat bahwa nilai siswa tidak mencapai ketuntasan minimal yang telah ditentukan dari sekolah karena untuk ketuntasan belajar peserta didik berdasarkan aturan yang telah diterapkan di SMP Negeri 1 Maros pada kelas VII, peserta didik dikategorikan tuntas pada mata pelajaran matematika jika mencapai ketuntasan minimal 75.

b. Deskripsi Data Prestasi Belajar Setelah Penerapan Model Pembelajaran cooperative tipe Two Stay Two Stray (TSTS) dengan Media Whatsapp.

Tabel 2. Rekapitulasi Prestasi Belajar Posttest

\begin{tabular}{|c|c|}
\hline & Posttest \\
\hline $\mathrm{N}$ & 12 \\
\hline Rata-rata & 84,25 \\
\hline Median & 86,50 \\
\hline Nilai Minimum & 70 \\
\hline Nilai Maksimum & 96 \\
\hline Standar Deviasi & 8,604 \\
\hline
\end{tabular}

Pada tabel dapat dlihat hasil dari tes setelah penerapan model pembelajaran cooperative tipe two stay two stray dengan media whatsapp, dengan jumlah siswa yang mengikuti 
posttest yaitu 12 siswa dari 32 siswa. Adapun nilai rata-rata dan median yg diperoleh siswa adalah 84,25 dan 86,50, sedangkan nilai minimum dan maksimum dari tes setelah diterapkan model pembelajaran cooperative tipe two stay two stray dengan media whatsapp adalah 70 dan 96. Dapat dilihat bahwa nilai siswa mencapai ketuntasan minimal yang telah ditentukan dari sekolah.

c. Pengaruh Model Pembelajaran Two Stay Two Stray dengan Media Whatsapp.

Tabel 3. Ketuntasan Belajar

\begin{tabular}{lcc}
\hline \multirow{2}{*}{ Ketuntasan Belajar } & \multicolumn{2}{c}{ Jumlah Siswa } \\
\cline { 2 - 3 } & Pretest & Posttest \\
\hline Tuntas & 0 & 10 \\
\hline TidakTundas & 12 & 2 \\
\hline & \multicolumn{2}{c}{ (Hasil penelitian, 2020) }
\end{tabular}

Pada tabel dapat dilihat ketuntasan belajar siswa dikatakan meningkat karena sebelum diterapkan model pembelajaran cooperative tipe two stay two stray pada media whatsapp terdapat 12 siswa yang tidak mencapai ketuntasan pada aturan yang telah ditetapkan di SMP Negeri 1 Maros pada kelas VII, peserta didik dikatakan tuntas pada mata pelajaran matematika jika mencapai nilai ketuntasan minimal 75 dan setelah diterapkan model pembelajaran cooperative tipe two stay two stray pada media whatsapp terdapat 10 dari 12 orang peserta didik yang dapat mencapai nilai ketuntasan, atau dengan kata lain ketuntasan belajar peserta didik yang dicapai pada kelas eksperimen sebesar $83,33 \%$.

Selanjutnya, untuk menggambarkan pengaruh yang terjadi setelah peserta didik diajar dengan menggunakan model pembelajaran cooperative tipe Two Stay Two Stray (TSTS) dengan media whatsapp, peneliti telah menganalisis skor gain ternormalisasi yang ditunjukkan pada tabel berikut:

Tabel 4. Gain Ternormalisasi Prestasi Belajar Matematika Peserta Didik

\begin{tabular}{cccccc}
\hline Sumber & Min & Max & Mean & Variansi & Std. Deviasi \\
\hline Skor Gain Ternormalisasi & 0,40 & 0,92 & 0,70 & 0,02 & 0,15 \\
\hline & & & & (Sumber: Analisis data dengan SPSS 24)
\end{tabular}

Pada tabel di atas menunjukkan bahwa ratarata gain ternormalisasi prestasi belajar siswa sebesar 0,70. Berdasarkan kategori gain ternormalisasi menunjukkan bahwa rata-rata gain ternormalisasinya berada pada kriteria tinggi. Artinya, secara klasikal prestasi belajar matematika siswa pada materi bangun datar segi empat setelah diajar dengan menerapkan model pembelajaran cooperative tipe two stay two stay dengan media whatsapp mengalami peningkatan yang tinggi.

\section{d. Analisis Inferensial}

Hasil Uji Prasyarat Analisis Hasil Penelitian statistik inferensial digunakan untuk membuat kesimpulan dari data yang diperoleh. Dalam hal ini, statistik inferensial digunakan untuk mengetahui ada peningkatan yang signifikan terhadap prestasi belajar matematika peserta didik Kelas VII-F SMP Negeri 1 setelah diajar 
dengan menerapkan model pembelajaran two stay two stray dengan media whatsapp. Uji statistik inferensial yang digunakan pada penelitian ini adalah uji Paired Sample T-Test. Namun sebelum melakukan uji tersebut, perlu dilakukan uji prasyarat. Namun sebelum melakukan uji tersebut, perlu dilakukan uji prasyarat. Uji prasyarat yang digunakan dalam menganalisis hasil penelitian ini adalah uji normalitas, dimana uji normalitas digunakan untuk mengetahui data yang digunakan berasal dari populasi yang berdistribusi normal atau tidak.

\section{Uji Normalitas}

Uji normalitas data yang digunakan dalam penelitian ini dilakukan dengan bantuan program aplikasi SPSS 24. Data berdistribusi normal jika nilai- $p$ pada uji Shapiro-Wilk lebih dari alpha $(\alpha)$. Dengan Hipotesis:

Ho : Data berasal dari populasi yang berdistriusi normal.

H1 : Data berasal dari populasi yang tidak berdistribusi normal.

Hipotesis statistiknya:

Ho $: \rho>0.05$ dan $\quad \mathrm{H} 1: \rho<0.05$

Kaidah Uji:

Ho diterima, jika: skor sig $>0.05$

Ho ditolak, jika: skor sig $<0.05$

Hasil komputasi pengujian normalitas data selengkapnya. Rangkuman hasilnya disajikan pada tabel berikut:

Tabel 5. Hasil Uji Normalitas

\begin{tabular}{ccccc}
\hline Sumber & Nilai- $\boldsymbol{p}$ & $\boldsymbol{\alpha}$ & Keputusan & Kesimpulan \\
\hline Gain Ternormalisasi & 0,40 & 0,92 & 0,70 & 0,02 \\
\hline & & & (Sumber: Analisis data dengan SPSS 24, 2020)
\end{tabular}

Berdasarkan hasil uji normalitas di atas, diproleh nilai- $p$ (sig) pada uji Shapiro Wilk lebih dari 0,05 sehingga dapat disimpulkan bahwa data dalam penelitian ini berasal dari populasi yang berdistribusi normal.

\section{Hasil Pengujian Hipotesis}

Uji hipotesis dalam penelitian ini digunakan paired sample t-test pada gain ternormalisasi.
Uji-t dalam penelitian ini digunakan untuk mengetahui peningkatan terhadap prestasi belajar matematika peserta didik setelah diterapkan model pembelajaran two stay two stray dengan media whatsapppada materi bangun datar segiempat.

Tabel 6. Paired Sample T-test

\begin{tabular}{cccc}
\hline Sumber & $\mathbf{t}_{\text {hitung }}$ & Nilai- $\boldsymbol{p}$ & Keputusan \\
\hline Gain Ternormalisasi Prestasi Belajar Matematika & 0,40 & 0,92 & Ho ditolak \\
\hline & \multicolumn{3}{c}{ (Sumber: Analisis data dengan SPSS 24, 2020) }
\end{tabular}


Berdasarkan rangkuman hasil analisis data pada tabel diatas diperoleh nilai $t_{\text {hitung }}=-16,191$ dengan nilai- $p=0,000<\frac{1}{2} \alpha=0,025$, maka sesuai dengan kriteria pengambilan keputusan untuk uji hipotesis dapat disimpulkan bahwa Ho ditolak. Artinya, ada peningkatan yang signifikan terhadap prestasi belajar matematika peserta didik Kelas VII-F SMP Negeri 1 Maros setelah diajar dengan menerapkan model pembelajaran cooperative tipe Two Stay Two Stray dengan media whatsapp.

\section{PEMBAHASAN}

Setelah dilakukan tes pada sampel untuk mengukur prestasi belajar pada peserta didik yang berupa soal pretest atau dalam hal ini tes yang diberikan kepada siswa sebelum diterapkan model pembelajaran cooperative tipe Two Stay Two Stray (TSTS) dengan media whatsapp dan mengambil salah satu materi pelajaran matematika yaitu segiempat dengan menerapkan model pembelajaran cooperative tipe Two Stay Two Stray dengan menggunakan media whatsapp, setelah penerapan model siswa diberikan soal posttest atau dalam hal ini tes yang diberikan kepada peserta didik setelah diterapkan model pembelajaran cooperative tipe Two Stay Two Stray (TSTS) dengan media whatsapp.

Pada post-test juga memperlihatkan terdapat 10 dari 12 orang peserta didik yang dapat mencapai nilai ketuntasan, atau dengan kata lain ketuntasan belajar peserta didik yang dicapai pada kelas eksperimen sebesar 83,33\%.
Selain itu, analisis inferensial juga menunjukkan fakta bahwa uji paired sample t-test dengan taraf signifikansi $\alpha=0,05$, diperoleh nilai Sig (2tailed) yakni 0,000. Karena Sig (2-tailed) $<\frac{1}{2} \alpha$ atau 0,025 , sesuai dengan kaidah pengujian hipotesis ini maka diketahui bahwa terdapat peningkatan yang signifikan terhadap prestasi belajar peserta didik Kelas VII F SMP Negeri 1 Maros setelah diajar dengan menerapkan model pembelajaran cooperative tipe Two Stay Two Stray dengan media whatsapp. Pengaruh yang signifikan terhadap prestasi belajar matematika peserta didik juga dapat dilihat melalui parameter nilai rata-rata gain ternormalisasi hasil belajar peserta didik yang mencapai 0,70 dengan kriteria tinggi, dimana skor gain ternormalisasi hasil belajar siswa terdistribusi pada kriteria sedang dan tinggi. Hal tersebut menunjukkan pengaruh yang signifikan terhadap prestasi belajar matematika peserta didik setelah diajar dengan menerapkan model pembelajaran cooperative tipe Two Stay Two Stray dengan media whatsapp

\section{E. PENUTUP}

Kesimpulan penelitian ini adalah Model Pembelajaran cooperative tipe Two Stay Two Stray (TSTS) dengan media whatsapp dapat memberikan pengaruh yang signifikan terhadap prestasi belajar matematika siswa kelas VII $F$ SMP Negeri 1 Maros, hal ini dapat dilihat pada nilai rata-rata sebelum dilakukan perlakuan model cooperative tipe Two Stay Two Stray dengan media whatsapp (PreTest) adalah 46,83 
dan nilai rata- rata setelah diberikan perlakuan model cooperative tipe Two Stay Two Stray dengan media whatsapp (PostTest) adalah 84,25 yang memiliki ketuntasan klasikalnya $83,33 \%$. Dan Rata-rata gain ternormalisasi hasil belajar siswa adalah 0,70 berada pada kategori tinggi. Nilai hasil analisis paired sample t-test diperoleh t-hitung $=-16,191$ dengan nilai- $\rho=0,000<$ $\frac{1}{2} \alpha=0,025$ sehingga terdapat peningkatan yang signifikan terhadap prestasi belajar matematika peserta didik Kelas VII F SMP Negeri 1 Maros setelah diajar dengan menerapkan model pembelajaran cooperative tipe Two Stay Two Stray (TSTS) dengan media whatsapp.

\section{DAFTAR PUSTAKA}

Amiluddin, R., \& Sugiman, S. (2016). Pengaruh Problem Posing Dan PBL Terhadap Prestasi Belajar, Dan Motivasi Belajar Mahasiswa Pendidikan Matematika. Jurnal Riset Pendidikan Matematika, 3(1), 100-108.

Andika, N. D., Usodo, B., \& Subanti, S. (2016). Eksperimentasi Model Pembelajaran Two Stay Two Stray (TSTS) Dan Think Pair Share (TPS) Dengan Pendekatan Saintifik Pada Materi Himpunan Ditinjau Dari Kecerdasan Logis-Matematis. Jurnal Elektronik Pembelajaran Matematika, 4(8), 830-840.

Ervitasari, A. (2018). Rendahnya Prestasi Siswa. Universitas Kristen Satya Wacana.

Gani, A. (2015). Pengaruh Model Pembelajaran Dan Persepsi Tentang Matematika Terhadap Minat Dan Hasil Belajar Matematika Siswa SMP Negeri Di Kecamatan Salomekko Kabupaten Bone. Jurnal Daya Matematis, 3(3), 337-343.
Hadijah. (2018). Efektivitas Model Problem Based Learning Dengan Bantuan Media Animasi Pada Materi Bangun Datar Segi Empat Terhadap Prestasi Belajar Matematika Peserta Didik Kelas VII SMP Negeri 5 Mandai. Universitas Muslim Maros.

Herin, P. M., \& Roniwijaya, M.Pd, Pd. airun. (2017). Penerapan Metode TSTS (Two Stay Two Stray) Untuk Meningkatkan Keaktifan Dan Hasil Belajar Melakukan Perbaikan Engine Berikut Komponen-Komponennya Siswa Kelas X Jurusan Teknik Sepeda Motor SMK Tamansiswa Naggulan 2015/2016. Jurnal Taman Vokasi, 5(1), 10-16.

Himawan, Madjis, R., Nur, R., \& Mei, N. (2018). Model Pembelajaran Sistem Perilaku. Yogyakarta: Universitas Negeri Yogyakarta.

Nasir, A. M. (2016). Statistik Pendidikan (Edisi Pertama). Yogyakarta: Media Akademi.

Nasir, A.M., Nirfayanti, N., (2019). Effectiveness Of Mathematic Learning Media Based On Mobile Learning In Improving Student Learning Motivation. Jurnal Inovasi Matematika, 7, 228-234.

Purnama, A. E., Usodo, B., \& Kuswardi, Y. (2018). Eksperimentasi Model Pembelajaran TSTS Berbasis Pendekatan Kontekstual Pada Materi Trigonometri Ditinjau Dari Keaktifan Belajar Siswa. Jurnal Pendidikan Matematika Dan Matematika (JPMM), 2(2), 127-133.

Supriatin, E., \& Wakijo. (2018). Pengaruh Penggunaan Model Cooperative Learning Tipe Two Stay Two Stray (TS-TS) Terhadap Hasil Belajar IPS Terpadu Siswa Kelas VIII. Jurnal Pendidikan Ekonomi UM Metro, 6(1), 1-8. 